International Journal of Environmental Research and

Public Health

ISSN 1660-4601

www.mdpi.com/journal/ijerph

Article

\title{
Observational Studies and a Statistical Early Warning of Surface Ozone Pollution in Tangshan, the Largest Heavy Industry City of North China
}

\section{Pei Li ${ }^{1,2,3}$, Jinyuan Xin ${ }^{2}{ }^{2}$, Xiaoping Bai ${ }^{1}$, Yuesi Wang ${ }^{2}$, Shigong Wang ${ }^{1}$, Shixi Liu ${ }^{2}$ and} Xiaoxin Feng ${ }^{4}$

1 College of Atmospheric Science, Lanzhou University, Lanzhou, Gansu 730000, China;

E-Mails: lipei@dq.cern.ac.cn (P.L.); baixp11@1zu.edu.cn (X.B.); wangsg@1zu.edu.cn (S.W.)

2 State Key Laboratory of Atmospheric Boundary Layer Physics and Atmospheric Chemistry, Institute of Atmospheric Physics, Chinese Academy of Sciences, Beijing 100029, China;

E-Mails: wys@dq.cern.ac.cn (Y.W.); 1sx@dq.cern.ac.cn (S.L.)

3 Unit 93534 of PLA, Beijing 101212, China

4 College of Material Science, Hebei United University, Tangshan, Hebei 063009, China;

E-Mail: fxxipac@163.com

* Author to whom correspondence should be addressed; E-Mail: xjy @ mail.iap.ac.cn;

Tel.: +86-10-6205-9568; Fax: +86-10-8208-0530.

Received: 31 January 2013; in revised form: 4 March 2013 / Accepted: 5 March 2013 /

Published: 13 March 2013

Abstract: Continuous measurements of surface ozone $\left(\mathrm{O}_{3}\right)$ and nitrogen oxides $\left(\mathrm{NO}_{\mathrm{X}}\right)$ at an urban site $\left(39^{\circ} 37^{\prime} \mathrm{N}, 118^{\circ} 09^{\prime} \mathrm{E}\right)$ in Tangshan, the largest heavy industry city of North China during summertime from 2008 to 2011 are presented. The pollution of $\mathrm{O}_{3}$ was serious in the city. The daily maximum $1 \mathrm{~h}$ means $\left(\mathrm{O}_{3-1} 1\right.$ hr max $)$ reached $157 \pm 55,161 \pm 54$, $120 \pm 50$, and $178 \pm 75 \mu \mathrm{g} / \mathrm{m}^{3}$ corresponding to an excess over the standard rates of $21 \%$, $27 \%, 10 \%$, and $40 \%$ in 2008-2011, respectively. The total oxidant level $\left(\mathrm{O}_{\mathrm{X}}=\mathrm{O}_{3}+\mathrm{NO}_{2}\right)$ was high, with seasonal average concentrations up to $100 \mu \mathrm{g} / \mathrm{m}^{3}$ in summer. The level of $\mathrm{O}_{\mathrm{X}}$ at a given location was made up of $\mathrm{NO}_{\mathrm{X}}$-independent and $\mathrm{NO}_{\mathrm{X}}$-dependent contributions. The independent part can be considered as a regional contribution and was about $100 \mu \mathrm{g} / \mathrm{m}^{3}$ in Tangshan. Statistical early warning analysis revealed that the $\mathrm{O}_{3}$ levels would exceed the standard rate by $50 \%$ on the day following a day when the daily average ozone concentration $\left(\mathrm{O}_{3 \_ \text {mean }}\right)$ exceeded $87 \mu \mathrm{g} / \mathrm{m}^{3}$ and the daily maximum temperature 
(T_max) exceeded $29^{\circ} \mathrm{C}$. The exceed-standard rate would reach $80 \%$ when $\mathrm{O}_{3 \_ \text {mean }}$ and $\mathrm{T}_{\_}$max exceeded $113 \mu \mathrm{g} / \mathrm{m}^{3}$ and $31{ }^{\circ} \mathrm{C}$. Similarly, the exceed-standard rate would reach $100 \%$ when $\mathrm{O}_{3 \_ \text {mean }}$ and $\mathrm{T}_{-}$max exceeded $127 \mu \mathrm{g} / \mathrm{m}^{3}$ and $33{ }^{\circ} \mathrm{C}$, respectively.

Keywords: Tangshan; ozone pollution; $\mathrm{O}_{3}$; nitrogen oxides; early warning; heavy industry city

\section{Introduction}

Ozone $\left(\mathrm{O}_{3}\right)$ in the lower part of the atmosphere (troposphere) is one of the most widespread global air pollution problems today. Evidence for the adverse effects of $\mathrm{O}_{3}$ on both human health and the environment at existing concentrations can currently be found in many developed countries, as well as developing countries [1-3]. Therefore, many countries and regions have established appropriate environmental standards for this pollutant, but human exposure to high concentrations of ground level ozone continues to be a serious problem in many areas in the US and China, despite the implementation of government-mandated emission control strategies [4,5]. The control of ground level ozone is more difficult than for many other primary pollutants because ozone is a secondary pollutant. The formation of ground level ozone depends on the intensity of solar radiation, the absolute concentrations of its precursors such as nitrogen oxides $\left(\mathrm{NO}_{\mathrm{X}}\right)$ and volatile organic compounds (VOCs), and the VOCs/ $\mathrm{NO}_{\mathrm{X}}$ ratios [6-8]. Owing to the chemical coupling of $\mathrm{O}_{3}$, nitric oxide (NO), and nitrogen dioxide $\left(\mathrm{NO}_{2}\right)$, the levels of $\mathrm{O}_{3}$ and $\mathrm{NO}_{2}$ are inextricably linked. Therefore, the response to reductions in the nitrogen oxides emissions is remarkably not linear, and any resultant reduction in the level of nitrogen dioxide is invariably accompanied by an increase in the air concentration of ozone $[9,10]$. Moreover, the increasing $\mathrm{O}_{3}$ background concentration influences local levels of $\mathrm{O}_{3}$, and $\mathrm{NO}_{2}$ and the efficiency of local emission controls. It is therefore necessary to obtain a thorough understanding of the relationships and the chemical coupling among $\mathrm{O}_{3}, \mathrm{NO}$, and $\mathrm{NO}_{2}$ under various atmospheric conditions.

A number of previous studies showed that tropospheric $\mathrm{O}_{3}$ was increasing in many countries and regions [9-14]. Recently, many Chinese scientific researchers have monitored and analyzed the pollution of $\mathrm{O}_{3}$ in the northwest, southeast and Beijing-Tianjin-Hebei regions of China [11,13,15-19]. Some studies found that the mountainous northwest area of the Beijing-Tianjin-Hebei region was a storage area for $\mathrm{O}_{3}$, where $\mathrm{O}_{3}$ and $\mathrm{O}_{\mathrm{X}}\left(=\mathrm{O}_{3}+\mathrm{NO}_{2}\right)$ levels were remarkably higher than in the Beijing-Tianjin-Hebei plain $[15,18]$, and $\mathrm{O}_{3}$ has become a serious threat to the environment during summertime in certain cities of China. The Beijing-Tianjin-Hebei Atmospheric Environment Monitoring Network was established by the Institute of Atmospheric Physics, Chinese Academy of Sciences (IPA, CAS). The results of the network showed that the complex atmospheric pollution exhibited high concentrations of $\mathrm{O}_{3}$ and fine particles and oxidation in summer, with ubiquitous regional sources [18]. To achieve a reduction in the comprehensive pollution of $\mathrm{O}_{3}$ and particulate matter will be a very serious and difficult challenge in the region $[16,18,19]$.

Tangshan is the largest heavy-industry city with a long history in the Beijing-Tianjin-Hebei regions. Coal emissions and photochemical smog pollution have increased dramatically with the rapid growth of Tangshan's industrial sector since the 1990s. According to the 2010 Report of the Tangshan 
Environmental Protection Agency (TEPA), the ambient air quality of Tangshan city has improved gradually in recent years [20]. However, the environmental pollution caused by industrial and transport emissions should not be viewed optimistically. The 2016 International Horticultural Exposition will soon be hosted by Tangshan City, and there is a great need to assess and improve the air quality of the city. Based on the monitoring data from 2008 to 2011, the present study investigated the relationships between ambient levels of $\mathrm{O}_{3}, \mathrm{NO}, \mathrm{NO}_{2}$, and $\mathrm{O}_{\mathrm{X}}$, and developed an early warning assessment method to provide a scientific basis for the prevention of air pollution in Tangshan.

\section{Materials and Methods}

The data were collected from 2008 to 2011 at the Tangshan station, a site of the Air Quality Monitoring Network, which was established by IPA, CAS and Hebei United University. Figure 1 shows the location of the Tangshan station within the Beijing-Tianjin-Hebei region.

Figure 1. Location of Tangshan station in the Beijing-Tianjin-Hebei region.

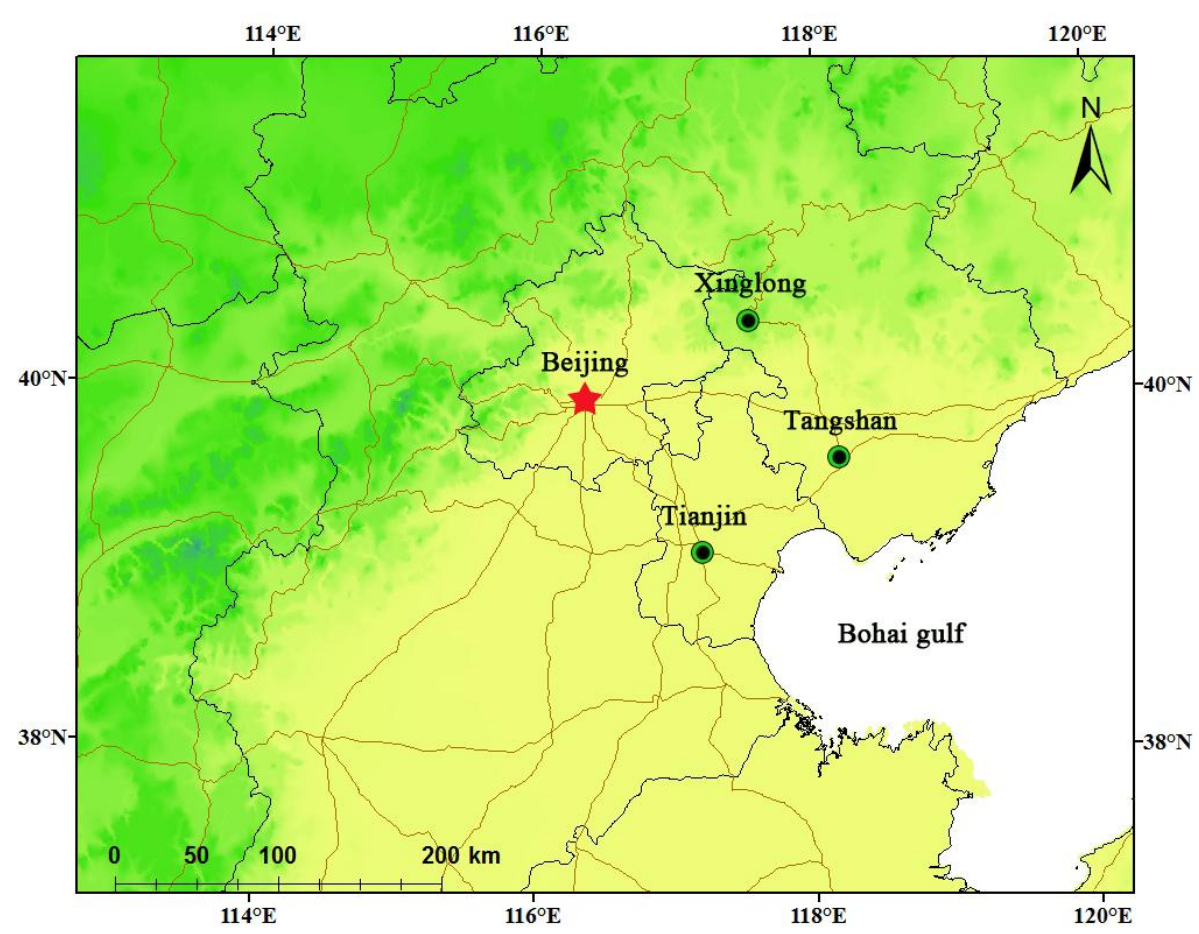

The station was in the urban center, located on the top of the four-layer office building of Hebei United University $\left(39^{\circ} 37^{\prime} \mathrm{N}, 118^{\circ} 09^{\prime} \mathrm{E}\right.$, the air intake was $12 \mathrm{~m}$ from the ground). Within a radius of about $5 \mathrm{~km}$ of the measured area, the land was relatively flat with some low residential buildings and commercial buildings, without remarkable point emission sources. The station was equipped with the online robotic instruments from Thermo Scientific (Franklin, MA, USA), including a 49I UV photometric $\mathrm{O}_{3}$ Analyzer and 42I NO-NO $2-\mathrm{NO}_{\mathrm{X}}$ precision chemiluminescence analyzers. Quality control checks, including automatic zero calibration and span checks of gas analyzers, were performed daily, and manual calibrations with standard gases were conducted weekly. Multi-point calibrations of the $\mathrm{O}_{3}$ analyzer used an $\mathrm{O}_{3}$ calibrator (TEI Model 49CPS, Franklin, MA, USA). The $\mathrm{NO}_{\mathrm{X}}$ analyzers have been zero-checked and span-checked using a zero gas generator (TEI Model 111, Franklin, MA, 
USA) and an internal $\mathrm{O}_{3}$ source of a multi-gas calibrator (TEI Model 146C, Franklin, MA, USA) with NO standard (National Centre for Standard Materials, Beijing, China). Sampling methods and instrument protocols, as well as quality assurance/quality control (QA/QC) procedures for air quality monitoring, were be executed based on the Chinese National Environmental Protection Standard, Automated Methods for Ambient Air Quality Monitoring. The real-time data was collected and transferred via the internet. The meteorological data were from actual Meteorological Information Comprehensive Analysis and Process System (MICAPS), which was established by the National Meteorological Center of China.

\section{Results and Discussion}

\subsection{Variation of $\mathrm{O}_{3}$ in Tangshan during the Summertime}

Table 1 shows the mean concentrations of atmospheric pollutants observed in Tangshan during the observation period. Total oxidant was taken to be the sum of $\mathrm{O}_{3}$ and $\mathrm{NO}_{2}$. The daily average $\left(\mathrm{O}_{3}\right.$ mean $)$, daily maximum $1 \mathrm{~h}$ mean $\left(\mathrm{O}_{3 \_1-\mathrm{h} \max }\right)$ and daily maximum $8 \mathrm{~h}$ mean $\left(\mathrm{O}_{3 \_8-\mathrm{h} \text { max }}\right)$ were used to describe the changes of $\mathrm{O}_{3}$ concentration. The seasonal average concentrations of $\mathrm{O}_{3 \_ \text {mean }}, \mathrm{O}_{3} \_1$-h max , and $\mathrm{O}_{3 \_} 8-\mathrm{h} \max$ were $69 \pm 28,154 \pm 61$, and $124 \pm 51 \mu \mathrm{g} / \mathrm{m}^{3}$ in summer during the 4 years study period, respectively. The lowest value of $\mathrm{O}_{3 \_ \text {mean }}$ was $53 \pm 22 \mu \mathrm{g} / \mathrm{m}^{3}$ in 2010 , and the highest was $79 \pm 35 \mu \mathrm{g} / \mathrm{m}^{3}$ in 2011 . The result is consistent with a previous study [17]. Xin et al. found that the daily average concentration of $\mathrm{O}_{3}$ were $69 \pm 22 \mu \mathrm{g} / \mathrm{m}^{3}$ in Beijing, $73 \pm 16 \mu \mathrm{g} / \mathrm{m}^{3}$ in its surrounding area (including the Tangshan city), and $100 \pm 25 \mu \mathrm{g} / \mathrm{m}^{3}$ in Xinglong during the Beijing 2008 Olympic Games, respectively [18]. Tang et al. found that were $66 \mu \mathrm{g} / \mathrm{m}^{3}$ and $54 \mu \mathrm{g} / \mathrm{m}^{3}$ in Beijing and its surrounding area from July to September during 2001-2006, respectively [16,19]. Compared with the above results, the pollution of $\mathrm{O}_{3}$ was very serious in the city, the same as in Beijing and its surrounding area.

Table 1. The mean concentrations of atmospheric pollutants observed in Tangshan in summer $\left(\mu \mathrm{g} / \mathrm{m}^{3}\right)$.

\begin{tabular}{|c|c|c|c|c|c|c|c|}
\hline \multirow{2}{*}{ Period } & \multicolumn{3}{|c|}{$\mathbf{O}_{3}$} & \multirow{2}{*}{ NO } & \multirow{2}{*}{$\mathrm{NO}_{2}$} & \multirow{2}{*}{ NO $_{x}$} & \multirow{2}{*}{$\mathbf{O}_{\mathbf{x}}$} \\
\hline & $\mathbf{O}_{3 \_ \text {mean }}$ & $\mathbf{O}_{3 \_1-h \text { max }}$ & $\mathbf{O}_{3 \_ \text {8-h max }}$ & & & & \\
\hline 2008: 06/01-09/30 & $75 \pm 25$ & $157 \pm 55$ & $129 \pm 46$ & $5 \pm 4$ & $41 \pm 10$ & $46 \pm 13$ & $116 \pm 27$ \\
\hline 2009: 07/13-09/30 & $69 \pm 29$ & $161 \pm 54$ & $126 \pm 52$ & $7 \pm 5$ & $43 \pm 10$ & $50 \pm 13$ & $113 \pm 28$ \\
\hline 2010: 06/01-09/30 & $53 \pm 22$ & $120 \pm 50$ & $97 \pm 42$ & $6 \pm 5$ & $47 \pm 13$ & $54 \pm 14$ & $100 \pm 32$ \\
\hline 2011: 06/01-08/10 & $79 \pm 35$ & $178 \pm 75$ & $143 \pm 64$ & $4 \pm 4$ & $39 \pm 10$ & $44 \pm 12$ & $118 \pm 36$ \\
\hline Mean & $69 \pm 28$ & $154 \pm 61$ & $124 \pm 51$ & $5 \pm 5$ & $43 \pm 11$ & $49 \pm 13$ & $112 \pm 31$ \\
\hline
\end{tabular}

The hourly averaged concentrations of $\mathrm{O}_{3}, \mathrm{NO}, \mathrm{NO}_{2}, \mathrm{NO}_{\mathrm{X}}$, and $\mathrm{O}_{\mathrm{X}}$ are shown in Figure 2. A distinct daily cycle of the pollutants was observed. In general, the daily cycle of $\mathrm{O}_{3}$ reached a peak during the middle of the day and had lower nighttime concentrations. The $\mathrm{O}_{3}$ concentration slowly increased as the sun rose, reached the maximum at 14:00, and then slowly decreased until 05:00 of the next morning. The daily cycle of $\mathrm{NO}, \mathrm{NO}_{2}$, and $\mathrm{NO}_{\mathrm{X}}$ concentration showed morning peaks and evening peaks. It can be seen that nitrogen oxides increased with increasing traffic in the morning and 
evening. $\mathrm{NO}$ is converted to $\mathrm{NO}_{2}$ via the reaction with $\mathrm{O}_{3}$ and during daylight hours, and $\mathrm{NO}_{2}$ is converted back to $\mathrm{NO}$ by photolysis, which also regenerates $\mathrm{O}_{3}[6,7,21,22]$. As long as $\mathrm{O}_{3}$ was present in excess, NO did not rise throughout the day. Since the photolysis rate at nighttime is zero there is net removal of $\mathrm{O}_{3}$ by $\mathrm{NO}$. The daily variation patterns of $\mathrm{O}_{3}$ and $\mathrm{O}_{\mathrm{X}}$ during the study period were similar.

Figure 2. Daily variation of mean concentrations of $\mathrm{O}_{3}, \mathrm{NO}, \mathrm{NO}_{2}, \mathrm{NO}_{\mathrm{X}}$, and $\mathrm{O}_{\mathrm{X}}$ during the summertime in Tangshan.

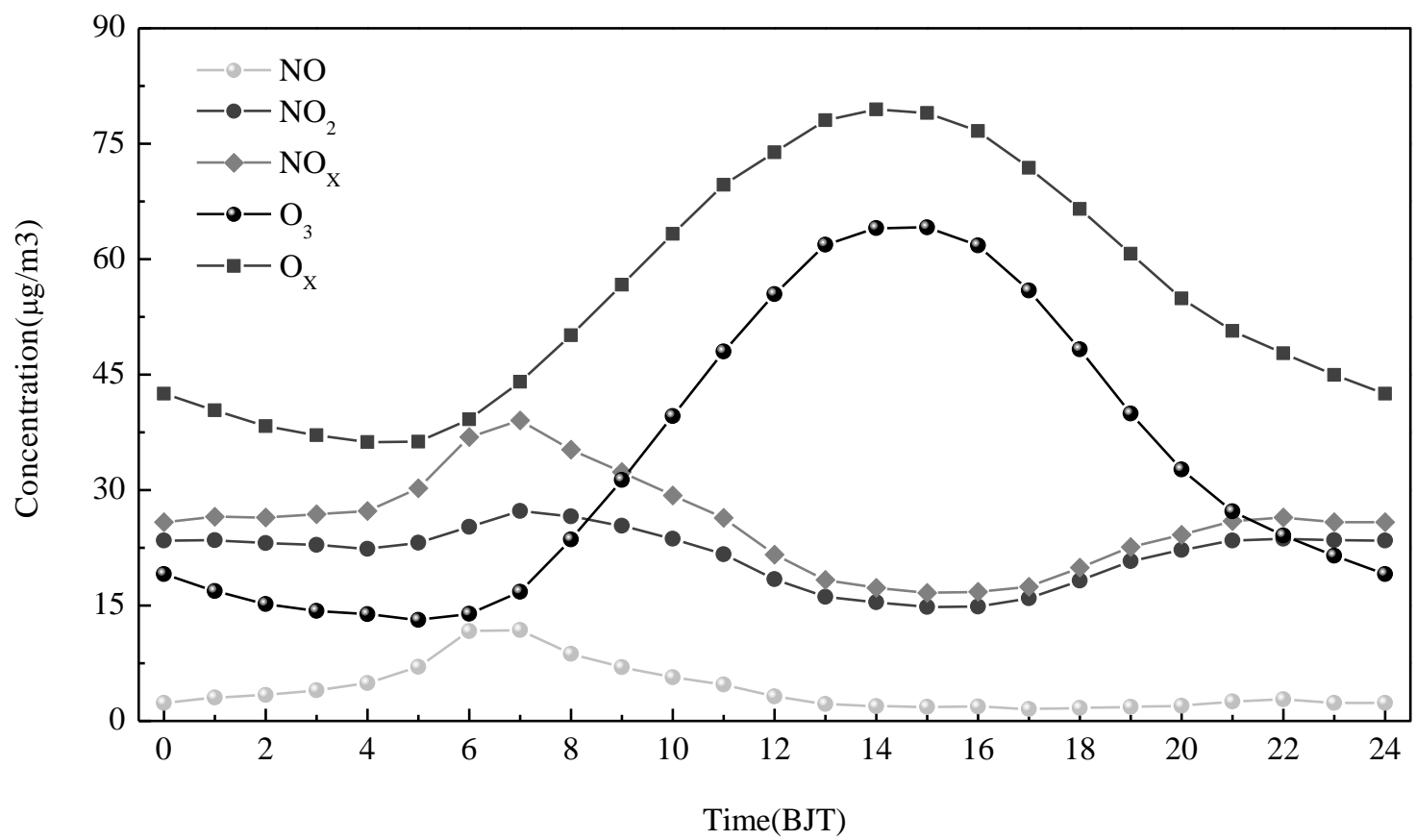

\subsection{Chemical Coupling of $\mathrm{O}_{3}, \mathrm{NO}$ and $\mathrm{NO}_{2}$}

Photochemical oxidants play key roles in the atmospheric pollution over urban areas. Among these, $\mathrm{O}_{3}$ and $\mathrm{NO}_{2}$ are important. Produced in the atmosphere through a set of complex reactions [9,10], they are capable of causing adverse impacts on human health and the environment. It is well established that the inter-conversion of $\mathrm{O}_{3}, \mathrm{NO}$ and $\mathrm{NO}_{2}$ under atmospheric conditions is generally dominated by the following Equations [21,22]:

$$
\begin{gathered}
\mathrm{NO}+\mathrm{O}_{3} \rightarrow \mathrm{NO}_{2}+\mathrm{O}_{2} \\
\mathrm{NO}_{2}+\mathrm{h} \gamma\left(+\mathrm{O}_{3}\right) \rightarrow \mathrm{NO}+\mathrm{O}_{3}
\end{gathered}
$$

In Equations (1)-(2), $\mathrm{NO}$ is initially oxidized by $\mathrm{O}_{3}$ to form $\mathrm{NO}_{2}$ which is then further converted to $\mathrm{O}_{3}$ through photolysis. Moreover, $\mathrm{O}_{3}$ can be consumed by a set of photochemical reactions. In polluted regions, however, peroxy radicals $\left(\mathrm{RO}_{2}\right)$ participate in Reaction (1) instead of $\mathrm{O}_{3}\left(\mathrm{NO}+\mathrm{RO}_{2} \rightarrow \mathrm{NO}_{2}+\mathrm{RO}\right)$. Under these conditions, pollution is caused by the accumulation of $\mathrm{O}_{3}$, if the concentration of $\mathrm{O}_{3}$ has reached a certain level. An analysis of the $\mathrm{NO}_{\mathrm{X}}$ cycle in the atmosphere can contribute to understanding the process of $\mathrm{O}_{3}$ pollution in Tangshan. The previous Equations cycle (1)-(2) allows a determination of the concentrations of these chemical species in this photostationary state, as shown by the following expression [19,21]: 


$$
\frac{[N O]\left[O_{3}\right]}{\left[N O_{2}\right]}=\frac{J_{2}}{K_{1}}
$$

In this expression, $\mathrm{J}_{2}$ is the rate of $\mathrm{NO}_{2}$ photolysis and $\mathrm{K}_{1}$ the rate coefficient for the reaction of $\mathrm{NO}$ with $\mathrm{O}_{3}$. Coefficient $\mathrm{J}_{2}$ is a function of the solar radiation intensity. Coefficient $\mathrm{K}_{1}$ is a function of the temperature. The variation of the mean values $J_{2} / K_{1}$ is shown in Figure 3 . The range of the mean $J_{2} / K_{1}$ was from 3 to $15 \mu \mathrm{g} / \mathrm{m}^{3}$ and the maximum occurred at 11:00.

Figure 3. Daily variation of mean values of $J_{2} / K_{1}\left(\mu \mathrm{g} / \mathrm{m}^{3}\right)$.

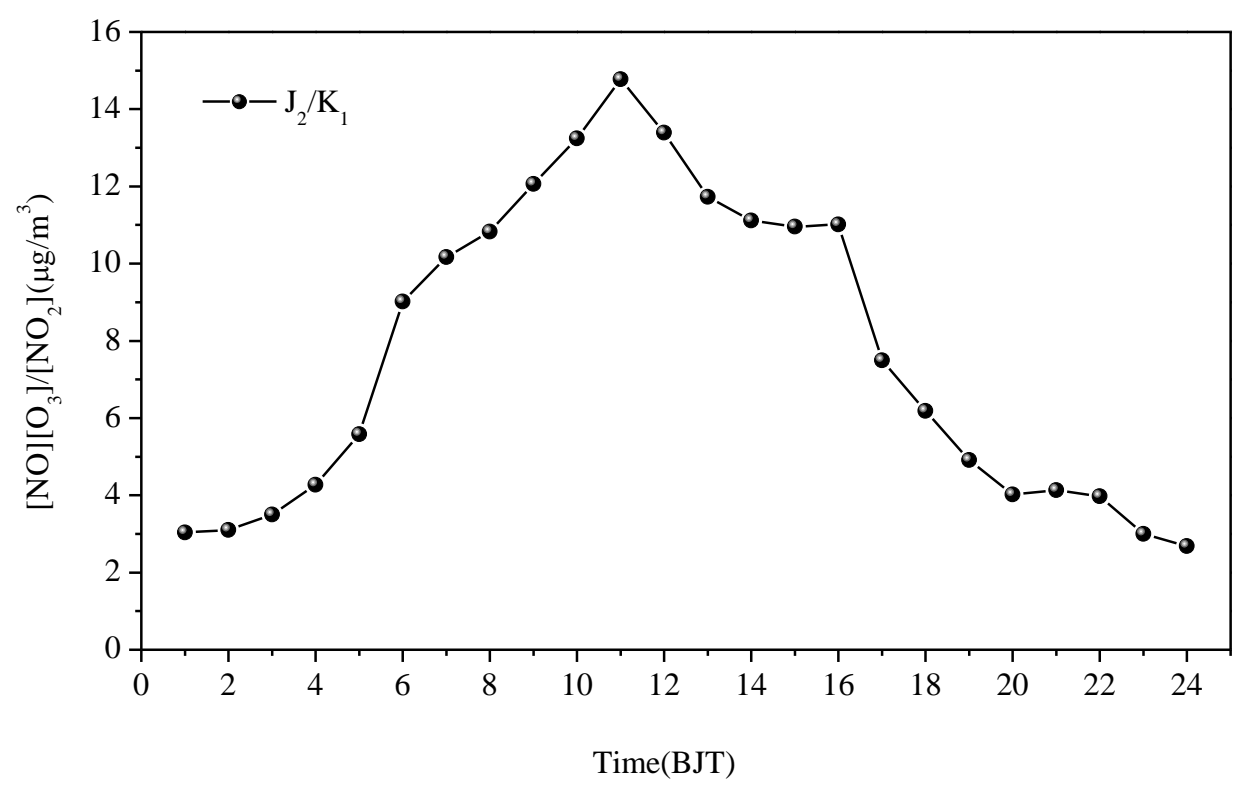

Figure 4. Variation of $\left[\mathrm{NO}_{2}\right] /\left[\mathrm{O}_{\mathrm{X}}\right]$ as a function of $\mathrm{NO}_{\mathrm{X}}$.

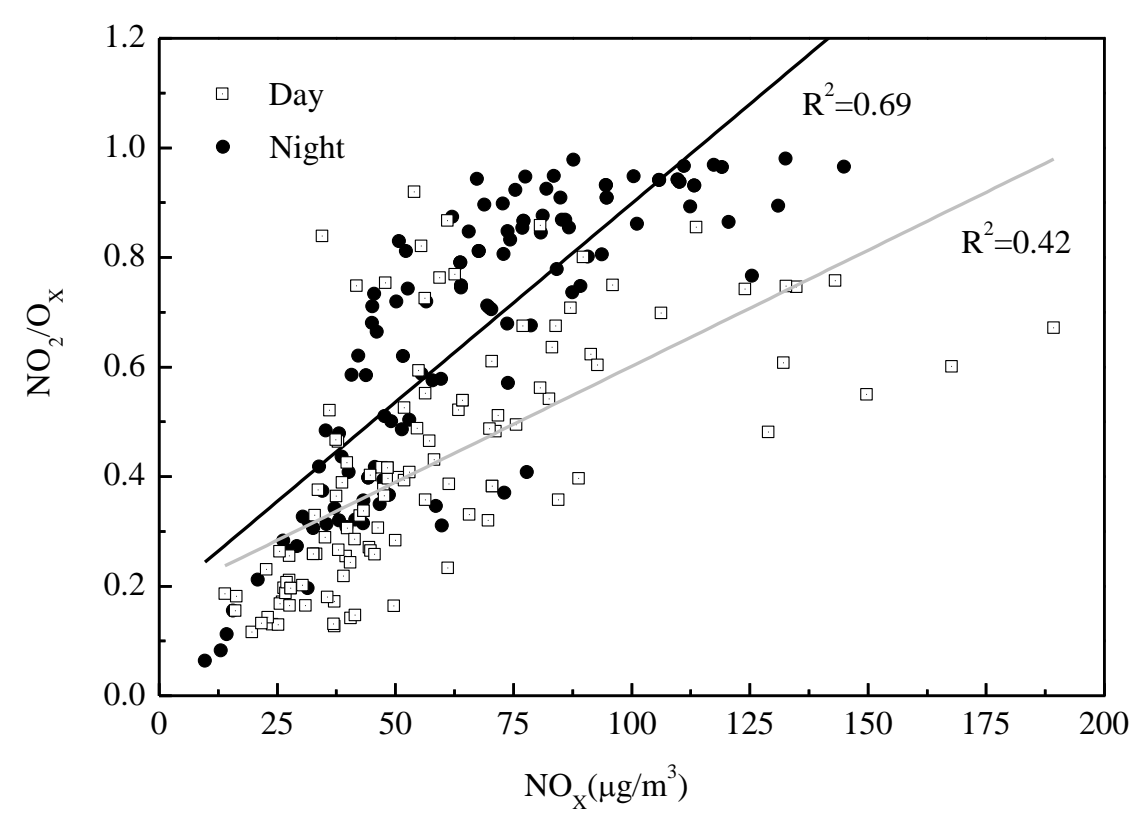

On the basis of the photostationary state relationship, it is possible to infer an expected variation of daily average $\left[\mathrm{NO}_{2}\right] /\left[\mathrm{O}_{\mathrm{X}}\right]$ values with $\left[\mathrm{NO}_{\mathrm{X}}\right]$. The variation of $\left[\mathrm{NO}_{2}\right] /\left[\mathrm{O}_{\mathrm{X}}\right]$ with $\mathrm{NO}_{\mathrm{X}}$ concentration is shown in Figure 4. It could be seen that the ratio of $\left[\mathrm{NO}_{2}\right] /\left[\mathrm{O}_{\mathrm{X}}\right]$ as a function of $\mathrm{NO}_{\mathrm{X}}$ was higher at 
night than during day. The greater portion of $\mathrm{O}_{\mathrm{X}}$ was in the form of $\mathrm{NO}_{2}$ at night. The day and night variation could be explained in terms of variation of the photolysis rate constant $\left(\mathrm{J}_{2}\right)$, which was a function of the solar radiation intensity and the time required for conversion of $\mathrm{NO}$ to $\mathrm{NO}_{2}$ (related to wind speed) [10]. At night $\mathrm{O}_{3}$ and $\mathrm{NO}$ cannot coexist and the conversion to $\mathrm{NO}_{2}$ occurs in a short time. Thus, more $\mathrm{NO}_{\mathrm{X}}$ was speciated as $\mathrm{NO}_{2}$ at night. Further, this showed that the reaction with freshly emitted $\mathrm{NO}$ and $\mathrm{O}_{3}$ via the $\mathrm{O}_{3}$ channel mainly controlled $\mathrm{NO}_{2}$ concentration and the $\mathrm{O}_{3}$ remaining after reaction with $\mathrm{NO}$ determined $\mathrm{O}_{3}$ concentration. This implied that the contribution of the $\mathrm{NO}_{\mathrm{X}}$ channel for $\mathrm{O}_{\mathrm{X}}$ production was major and the radical channel was minor. The residual $\mathrm{O}_{3}$ remaining after the $\mathrm{NO}-\mathrm{NO}_{2}-\mathrm{O}_{3}$ reaction controlled the $\mathrm{O}_{3}$ concentration in the urban atmosphere during the monitoring period.

The observed variation of daylight average concentrations of $\mathrm{O}_{3}, \mathrm{NO}$, and $\mathrm{NO}_{2}$ with the total level of $\mathrm{NO}_{\mathrm{X}}$ is shown in Figure 5. The lines in Figure 5 were fitted using the multiple regression method to investigate the assumption of a photostationary state. The curves of $\left[\mathrm{O}_{3}\right]$ and $[\mathrm{NO}]$ indicated that the $\left[\mathrm{NO}_{\mathrm{X}}\right]$ crossover point occurred at about $160 \mu \mathrm{g} / \mathrm{m}^{3}$. When $\left[\mathrm{NO}_{\mathrm{X}}\right]<160 \mu \mathrm{g} / \mathrm{m}^{3}, \mathrm{O}_{3}$ levels were higher than the NO levels, whereas NO dominated at higher $\left[\mathrm{NO}_{\mathrm{X}}\right]$. The intersection point of the curves represented the two oxidants as $\left[\mathrm{NO}_{\mathrm{X}}\right]=100 \mu \mathrm{g} / \mathrm{m}^{3}$. When $\left[\mathrm{NO}_{\mathrm{X}}\right]<100 \mu \mathrm{g} / \mathrm{m}^{3} \mathrm{O}_{3}$ was the dominant form and $\mathrm{NO}_{2}$ dominated at higher $\left[\mathrm{NO}_{\mathrm{X}}\right]$ levels. This pattern was consistent with other research results $[10,23,24]$, although the intersection points vary with local conditions.

Figure 5. Variations of daylight average concentrations of $\mathrm{O}_{3}, \mathrm{NO}$, and $\mathrm{NO}_{2}$ with the level of $\mathrm{NO}_{\mathrm{X}}$.

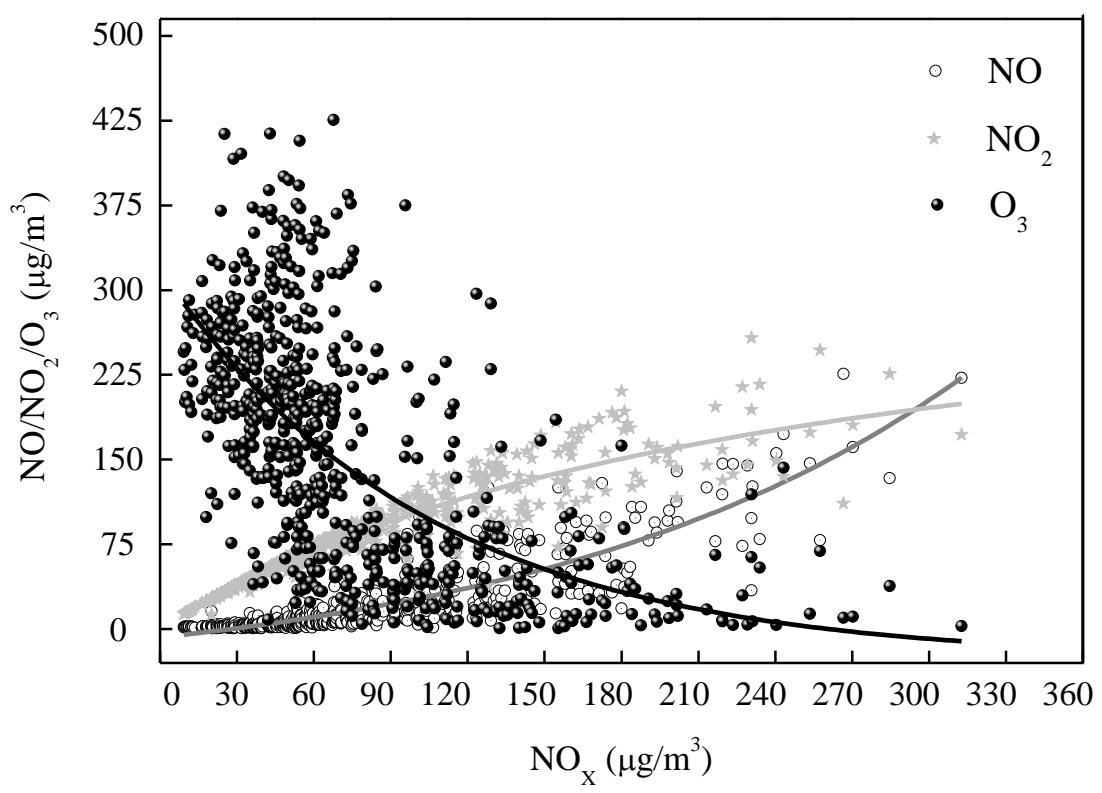

\subsection{Local and Regional Contributions to Oxidant}

The variation of daylight and nighttime values of $\mathrm{O}_{\mathrm{X}}$ concentration with the level of $\mathrm{NO}_{\mathrm{X}}$ are included in Figure 6. 
Figure 6. Variation of daily average $\mathrm{O}_{\mathrm{X}}$ with level of $\mathrm{NO}_{\mathrm{X}}$.

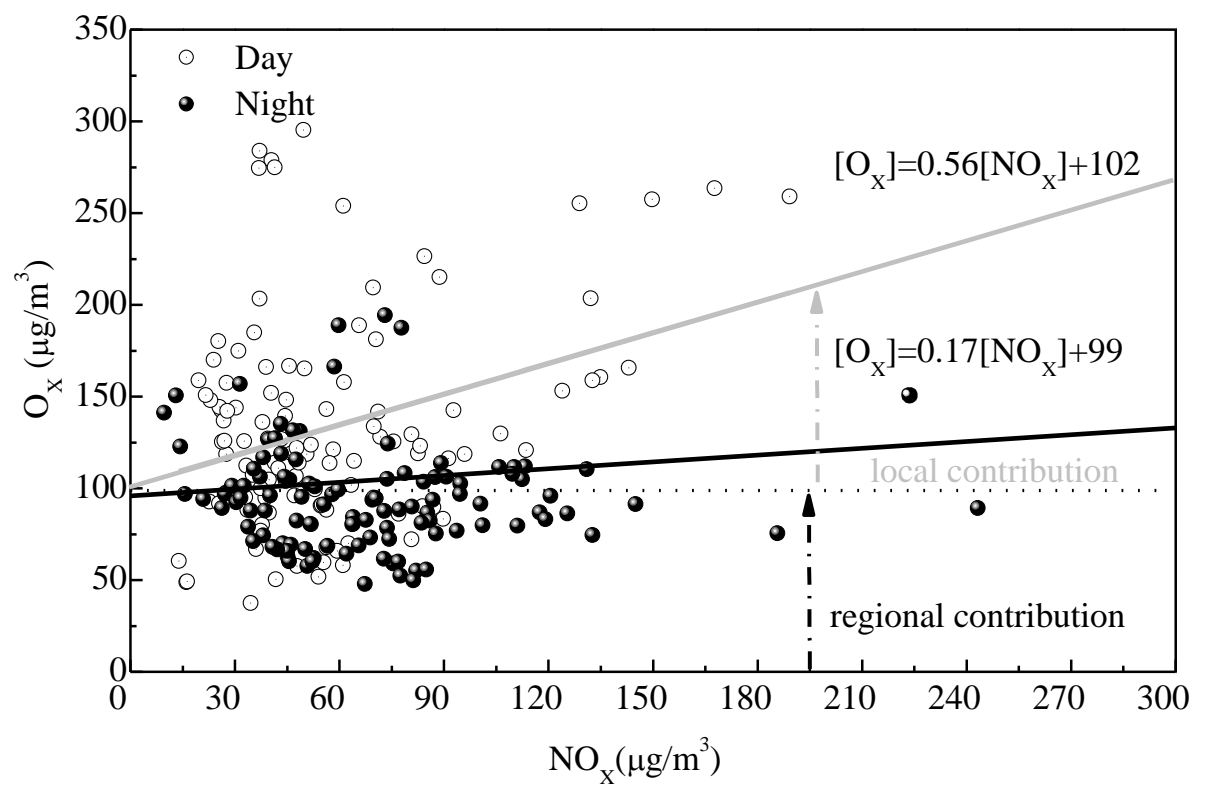

Total $\left[\mathrm{O}_{\mathrm{X}}\right]$ increased with $\mathrm{NO}_{\mathrm{X}}$, where the data were fitted by linear regression. Due to the influence of the photochemical reactions on the formation of $\mathrm{O}_{3}$, there were differences in the values and the linearly fitted equations between daytime and night. It could be observed that the total $\mathrm{O}_{\mathrm{X}}$ at a given location had an $\mathrm{NO}_{\mathrm{X}}$-independent contribution, and an $\mathrm{NO}_{\mathrm{X}}$-dependent contribution. The former was effectively a regional contribution which equated to the regional background $\mathrm{O}_{3}$ level, whereas the latter was effectively a local contribution which was correlated with the level of primary pollution. It was found that the $\mathrm{NO}_{\mathrm{X}}$-dependent local contribution to $\mathrm{O}_{\mathrm{X}}$ at nighttime was $25 \%$ lower than during the daytime. However, the regional contribution, approximately to $100 \mu \mathrm{g} / \mathrm{m}^{3}$, was almost equivalent during both day and night. The regional contribution to $\mathrm{O}_{3}$ was highly consistent with the values observed at Xinglong, which is the background station of the Beijing-Tianjin-Hebei region [18]. This result implied that $\mathrm{O}_{3}$ pollution had a similar source throughout the Beijing-Tianjin-Hebei region. It implied that the air quality problem in Tangshan was not only a local problem mainly from street-level pollutions, but also a regional problem from the Beijing-Tianjin-Hebei region. The territorial character of $\mathrm{O}_{3}$ pollution was consistent with the results reported by Xin et al. [18].

\subsection{Ozone Assessment and Early Warning}

Based on the National Ambient Air Quality Standards (NAAQS) which will be implemented in 2016 in China, the urban air quality standards of level II for the $1 \mathrm{~h}$ average and $8 \mathrm{~h}$ average of the $\mathrm{O}_{3}$ concentration were used in this paper. These standards specify a concentration not to exceed $160 \mu \mathrm{g} / \mathrm{m}^{3}$ and $200 \mu \mathrm{g} / \mathrm{m}^{3}$, respectively. Table 2 shows the results for the $\mathrm{O}_{3}$ exceed-standard days and exceed-standard rates based on the level II standards. The exceed-standard rates were very high in summer and were 22\%, 28\%, 10\%, and 41\% during 2008, 2009, 2010, and 2011, respectively. The highest value (38\%) appeared in June, and the lowest value (8.3\%) appeared in September. Except in 2010, the number of exceed-standard days during the past 4 years exceeded 25, and the exceed-standard rates exceeded $20 \%$ (Table 2). The exceed-standard rates calculated by $8 \mathrm{~h}$ average 
standard were $2.2 \%$ higher than those by 1-hour average standard of level II. Therefore, the Tangshan government would need to assume stricter control of $\mathrm{O}_{3}$ pollution over the coming years.

Table 2. Exceed-standard days and exceed-standard rates in Tangshan during the past four years.

\begin{tabular}{ccccccccccc}
\hline & \multicolumn{2}{c}{$\mathbf{2 0 0 8}$} & \multicolumn{2}{c}{$\mathbf{2 0 0 9}$} & \multicolumn{2}{c}{$\mathbf{2 0 1 0}$} & \multicolumn{2}{c}{$\mathbf{2 0 1 1}$} & \multicolumn{2}{c}{ Mean } \\
\cline { 2 - 10 } & No. & Rates & No. & Rates & No. & Rates & No. & Rates & No. & Rates \\
\hline 1-h & 25 & $21 \%$ & 21 & $27 \%$ & 10 & $10 \%$ & 27 & $40 \%$ & 83 & $23 \%$ \\
8-h & 29 & $24 \%$ & 23 & $29 \%$ & 10 & $10 \%$ & 29 & $43 \%$ & 91 & $25 \%$ \\
\hline Mean & 54 & $22 \%$ & 44 & $28 \%$ & 20 & $10 \%$ & 56 & $41 \%$ & 174 & $24 \%$ \\
\hline
\end{tabular}

Several methods were employed in ozone forecasting in many studies, such as Principal Components Analysis (PCA) which is a statistical technique used to investigate the structure of a data sets [25-29], Artificial Neural Networks (ANN) which is a mathematical model capable of determining a non-linear relationship between two data sets [30-33], Support Vector Machines (SVM) which have become more popular for air quality prediction [34-36], etc. Previous studies had shown that the temperature, humidity, and wind speed can affect the formation of $\mathrm{O}_{3}$, but high temperatures, low humidities and low wind speeds may not have contributed to a high concentration of $\mathrm{O}_{3}$ in all cases [7,37-39]. It was also indicated that the formation of $\mathrm{O}_{3}$ was a strongly coupled and complex nonlinear multivariable process [40].

We analyzed the meteorological factors selected to represent the relevant conditions, such as the temperature $\left(\mathrm{T}_{-}\right.$mean, $\mathrm{T}_{-}$max $)$, dew point temperature $\left(\mathrm{Td}_{-}\right.$mean $)$, depression of the dew point $\left(\mathrm{Ttd}_{-}\right.$mean $)$, wind speed (WS_mean), visibility (Vis_mean), $24 \mathrm{~h}$ isallobaric value $\left(\Delta \mathrm{P}_{24}\right)$, and $24 \mathrm{~h}$ isallotherm value $\left(\Delta \mathrm{T}_{24}\right)$. The $\mathrm{O}_{\mathrm{X} \_ \text {mean }}, \mathrm{O}_{3 \_ \text {mean }}, \mathrm{NO}_{\_}$mean $, \mathrm{NO}_{2 \_ \text {mean }}, \mathrm{NO}_{\mathrm{X} \_ \text {mean }}$, and $\left[\mathrm{NO} / \mathrm{NO}_{2}\right]_{-}$mean were also introduced in this paper. Table 3 shows the correlation coefficients between the selected factors on the current day and the $\mathrm{O}_{3}$ concentrations at the following day.

Table 3. Coefficients of correlation between 15 factors and $\mathrm{O}_{3}$ concentrations in the next day.

\begin{tabular}{|c|c|c|c|c|c|c|c|}
\hline & Factor & $\mathbf{O}_{3_{-1}-\mathrm{h} \text { max }}$ & $\mathbf{O}_{3 \_ \text {-8-h max }}$ & & Factor & $\mathbf{O}_{3_{-} 1-\mathrm{h} \text { max }}$ & $\mathbf{O}_{3 \_8-\mathrm{h} \text { max }}$ \\
\hline 1 & $\mathrm{~T}_{- \text {mean }}$ & $0.38^{* * *}$ & $0.39^{* *}$ & 9 & $\Delta \mathrm{T}_{24}$ & -0.01 & -0.01 \\
\hline 2 & $\mathrm{~T}_{\text {_max }}$ & $0.45^{* *}$ & $0.46^{* *}$ & 10 & $\mathrm{O}_{\mathrm{X} \_ \text {mean }}$ & $0.45^{* *}$ & $0.45^{* *}$ \\
\hline 3 & $\mathrm{Td}_{- \text {mean }}$ & $0.28^{* *}$ & $0.24^{* * *}$ & 11 & $\mathrm{O}_{3 \_ \text {mean }}$ & $0.54^{* * *}$ & $0.57^{* *}$ \\
\hline 4 & $\mathrm{Ttd}_{\text {mean }}$ & 0.11 & 0.13 & 12 & $\mathrm{NO} \_$mean & $-0.24^{* *}$ & $-0.24^{* *}$ \\
\hline 5 & $\mathrm{RH}_{-}$mean & $-0.12^{*}$ & $-0.14^{*}$ & 13 & $\mathrm{NO}_{2 \_ \text {mean }}$ & $-0.19^{*}$ & -0.22 * \\
\hline 6 & $\mathrm{WS}_{\text {_mean }}$ & $-0.17^{*}$ & $-0.14^{*}$ & 14 & $\mathrm{NO}_{\mathrm{x} \_ \text {mean }}$ & $-0.27^{*}$ & $-0.27^{*}$ \\
\hline 7 & Vis_mean & 0.03 & 0.09 & 15 & {$\left[\mathrm{NO} / \mathrm{NO}_{2}\right]_{- \text {mean }}$} & $-0.15^{*}$ & $-0.19^{*}$ \\
\hline 8 & $\Delta \mathrm{P}_{24}$ & 0.08 & 0.09 & & & & \\
\hline
\end{tabular}

Figure 7 shows 2 two indicators which have been chosen to represent the $\mathrm{O}_{3}$ concentration on the following day. The maximum $\mathrm{R}$-square value observed in these analyses 0.35 , was found for $\mathrm{O}_{3 \_ \text {mean }}$. 
The next highest value 0.15 , was found for $T_{-} \max ($ Figure 7$)$. For all of the functions used in the analysis, the remaining factors had consistently weak effects on the $\mathrm{O}_{3}$ concentration. It implied that $\mathrm{O}_{3 \text { _mean }}\left(\mathrm{X}_{1}\right)$ and $\mathrm{T}_{-}$max $\left(\mathrm{X}_{2}\right)$ had more significant effects on the $\mathrm{O}_{3}$ concentration of the next day. A multiple nonlinear regression equation corresponding to these factors was:

$$
\begin{aligned}
& \mathrm{Y}=0.005 \mathrm{X}_{1}^{2}+0.487 \mathrm{X}_{2}^{2}-0.091 \mathrm{X}_{1} \mathrm{X}_{2}+2.524 \mathrm{X}_{1}-16.434 \mathrm{X}_{2}+209.977\left(\mathrm{R}^{2}=0.21,\right. \\
& P<0.001) .
\end{aligned}
$$

Figure 7. The changes of $\mathrm{O}_{3 \_} 8$-hr max at the following day in the response to (a) ozone concentration; (b) temperature on the first day during the study periods.

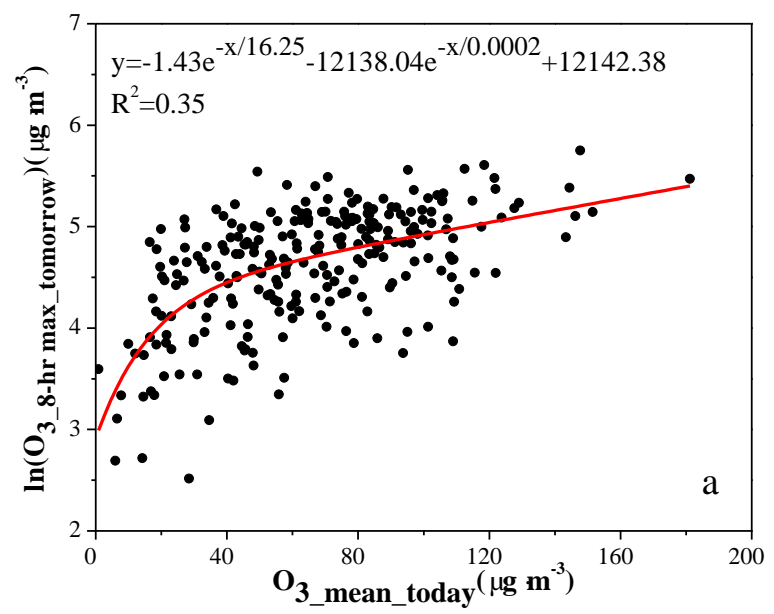

(a)

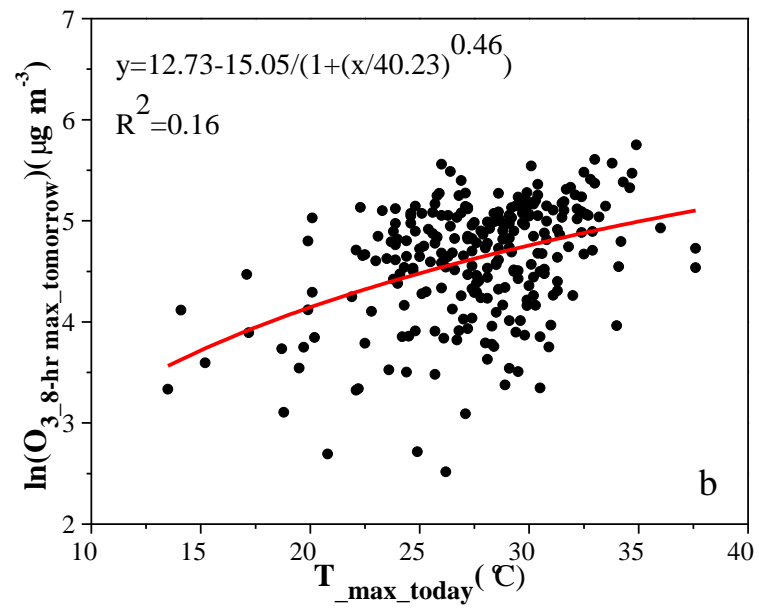

(b)

Using the multiple nonlinear regression equation, we can estimate the exceed-standard rate of $\mathrm{O}_{3}$ in the next day. Under stable meteorological conditions, when the $\mathrm{O}_{3 \text { _mean }}$ was less than $36 \mu \mathrm{g} / \mathrm{m}^{3}$ and $\mathrm{T}_{-}$max was less than $24^{\circ} \mathrm{C}$, the next day's $\mathrm{O}_{3}$ concentration would not exceed the urban air quality standards of level II, the exceed-standard rate at the following day equivalent to 0 .

Figure 8 shows the exceed-standard rates of $\mathrm{O}_{3}$ at the following day associated with an increase of $1 \mu \mathrm{g} / \mathrm{m}^{3}$ on the first day. The figure also indicated the changes of $\mathrm{T}_{-} \max$ as the concentration of $\mathrm{O}_{3}$ exceeded the standard. An exceed-standard rate of 50\% can be defined as the level 1 early warning for $\mathrm{O}_{3}$ pollution, an exceed-standard rate of $80 \%$ can be defined as the level 2 early warning for $\mathrm{O}_{3}$ pollution, an exceed-standard rate of $100 \%$ can be defined as the level 3 early warning for $\mathrm{O}_{3}$ pollution. The following results were obtained from the curve fitting and statistical analysis used in this study. It showed that under stable meteorological conditions, if $\mathrm{O}_{3 \_ \text {mean }}$ was less than $36 \mu \mathrm{g} / \mathrm{m}^{3}$ and T_max was less than $24^{\circ} \mathrm{C}$, the exceed-standard rate at the following day would be 0 ; if the $\mathrm{O}_{3}$ mean was higher than $87 \mu \mathrm{g} / \mathrm{m}^{3}$ and $\mathrm{T}_{\text {max }}$ was higher than $29{ }^{\circ} \mathrm{C}$, the exceed-standard rate would reach 50\%; if the $\mathrm{O}_{3 \_ \text {mean }}$ was greater than $113 \mu \mathrm{g} / \mathrm{m}^{3}$ and $\mathrm{T}_{-} \max$ was greater than $31{ }^{\circ} \mathrm{C}$, the exceed-standard rate would reach $80 \%$; if the $\mathrm{O}_{3 \_ \text {mean }}$ was greater than $127 \mu \mathrm{g} / \mathrm{m}^{3}$ and $\mathrm{T}_{-}$max was greater than $33{ }^{\circ} \mathrm{C}$, the exceed-standard rate would reach $100 \%$. 
Figure 8. The corresponding exceed-standard ratios at the following day of (a) $\mathrm{O}_{3 \_ \text {- } \mathrm{h} \text { max }}$ and (b) $\mathrm{O}_{3-1 \text {-h } \max }$ on the current day, and the corresponding max temperature on the current day when (c) $\mathrm{O}_{3 \_8-\mathrm{h} \max }$, and (d) $\mathrm{O}_{3-1-\mathrm{h} \max }$ exceed the standard at the following day.
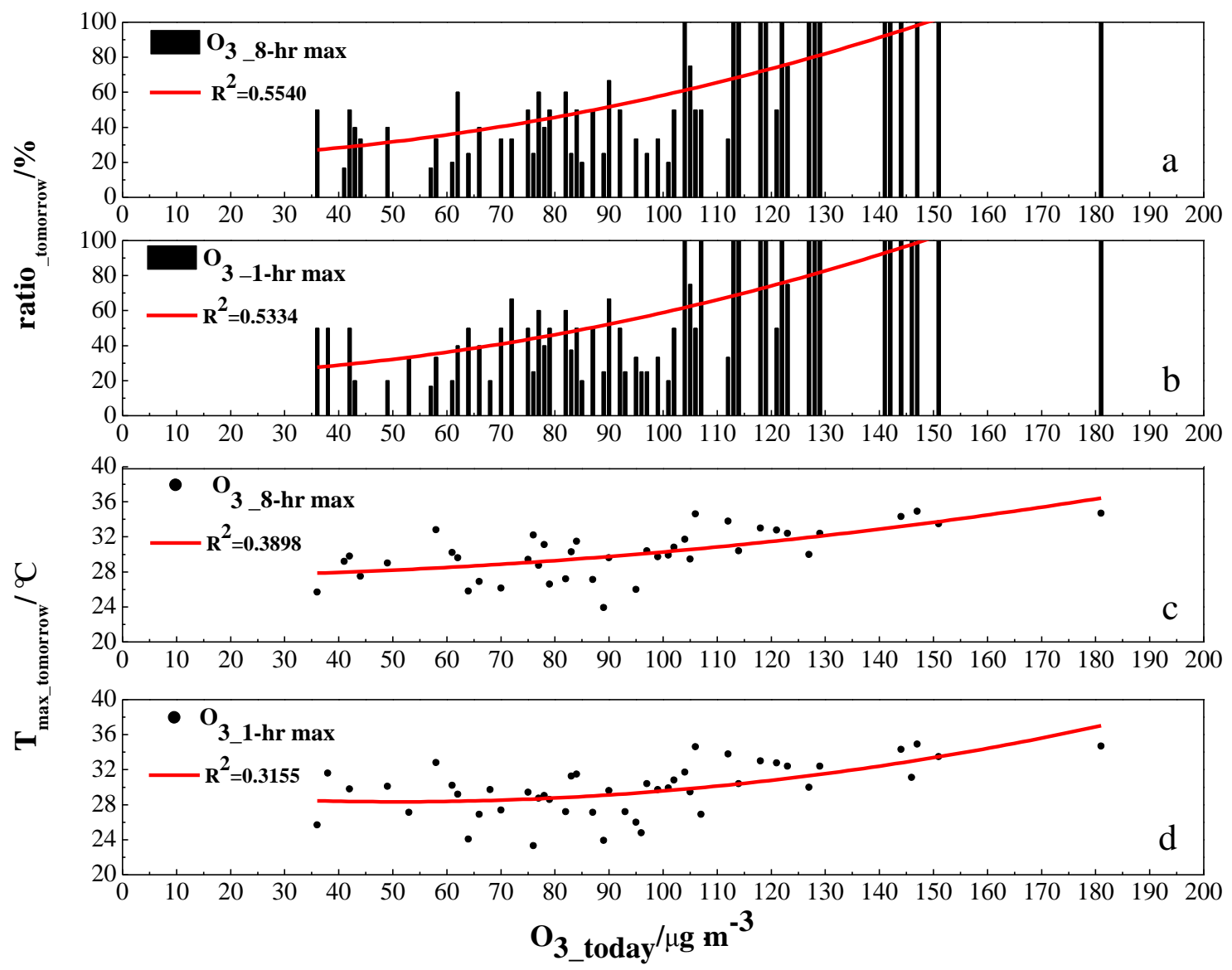

\section{Conclusions}

Tangshan city is the largest heavy-industry city in North China. In recent decades, the economical development was very rapid, leading to serious air pollution. The observations showed that the concentrations of $\mathrm{O}_{3}$ and $\mathrm{O}_{\mathrm{X}}$ were very high in summer. The pollution of $\mathrm{O}_{3}$ in Tangshan was not only a local problem resulting mainly from street-level pollution, but also a regional problem from the Beijing-Tianjin-Hebei region. With the statistical analysis of the long-term data, we developed a simple method to assess the exceed-standard rate of $\mathrm{O}_{3}$ at the following day. The short-term early warning method would strengthen the capability to prevent regional atmospheric pollution accidents. In conjunction with other methods, the method could be used to estimate some governmental control strategies for photochemical pollutants in Tangshan city.

\section{Acknowledgments}

This work was partially supported by the National Natural Science Foundation of China (41222033, 41021004), the CAS Strategic Priority Research Program Grant (XDA05100102, XDB05020200), 
the Gong-Yi Program of China Meteorological Administration (GYHY201106034), and the Research Subject of State Science and Technology Support Program of China (2012BAJ18B08).

\section{References}

1. Ramzi, M.K.; James, K. Ozone enhances Diesel Exhaust Particles (DEP)-induced interleukin-8 (IL-8) gene expression in human airway epithelial cells through activation of nuclear factors-kappaB (NF-kappaB) and IL-6 (NF-IL6). Int. J. Environ. Res. Public Health 2005, 2, 403-410.

2. World Health Organization. Air Quality Guidelines for Particulate Matter, Ozone, Nitrogen Dioxide and Sulfur Dioxide-Global Update, 2005. Available online: http://whqlibdoc.who.int/hq/ 2006/WHO_SDE_PHE_OEH_06.02_eng.pdf (accessed on 18 December 2012).

3. Lee, D.S.; Holland, M.K.; Falla, N. The potential impact of ozone on materials in the UK. Atmos. Environ. 1996, 30, 1053-1065.

4. Duanjun, L.; Remata, S.R.; Rosa, F.; William, R.S.; Quinton, L.W.; Paul, B.T. Sensitivity odeling study for an ozone occurrence during the 1996 Paso Del Norte ozone campaign. Int. J. Environ. Res. Public Health 2008, 5, 181-203.

5. Roselle, S.J.; Pierce, T.E.; Schere, K.L. The sensitivity of regional ozone modeling to biogenic hydrocarbons. J. Geophys. Res. 1991, 96, 7371-7394.

6. Tang, X.Y.; Zhang, Y.H.; Shao, M. Chemistry of the Atmospheric Environment (in Chinese), 2nd ed.; Higher Education Press: Beijing, China, 2006.

7. Logan, J.A.; Prather, M.J.; Wofsy, S.C. Troposphere chemistry: A global perspective. J. Geophys. Res. 1981, 86, 7210-7254.

8. Geng, F.H.; Tie, X.X.; Xu, J.M.; Zhou, G.Q.; Peng, L.; Gao, W.; Tang, X.; Zhao, C.S. Characterizations of ozone, $\mathrm{NO}_{X}$, and VOCs measured in Shanghai, China. Atmos. Environ. 2008, 42, 6873-6883.

9. Lynette, J.C.; Michael, E.J. Analysis of the relationship between ambient levels of $\mathrm{O}_{3}, \mathrm{NO}_{2}$ and $\mathrm{NO}$ as a function of $\mathrm{NO}_{X}$ in the UK. Atmos. Environ. 2001, 35, 6391-6405.

10. Mazzeo, N.A.; Venegasa, L.E.; Choren, H. Analysis of $\mathrm{NO}, \mathrm{NO}_{2}, \mathrm{O}_{3}$ and $\mathrm{NO}_{X}$ concentrations measured at a green area of Buenos Aires City during wintertime. Atmos. Environ. 2005, 39, 3055-3068.

11. Wang, S.G.; Zhang, L.; Chen, C.H.; Yuan, J.Y. Retrospect and prospect for the studies of atmospheric environment in the Lanzhou area (in Chinese). J. Lanzhou Univ. 1999, 35, 189-204.

12. Lu, W.Z.; Wang, X.K.; Wang, W.J.; Leung, A.Y.T.; Yuen, K.K. A preliminary study of ozone trend and its impact on environment in Hong Kong. Environ. Int. 2002, 28, 503-512.

13. Wang, X.S.; Li, J.L.; Zhang, Y.H.; Xie, S.D.; Tang, X.Y. Ozone source attribution during a severe photochemical smog episode in Beijing, China. Sci. Chin. B Chem. 2009, 39, 548-559.

14. Lee, Y.C.; Calori, G.; Hills, P.; Carmichael, G.R. Ozone episodes in urban Hong Kong 1994-1999. Atmos. Environ. 2002, 36, 1957-1968.

15. Zheng, X.D.; Ding, G.A.; Yu, H.Q.; Liu, Y.; Xu, X.D. Vertical distribution of ozone in the planetary boundary layer at the Ming Tombs, Beijing. Sci. Chin. Ser. D Sci. 2005, 35, 45-52.

16. Tang, G.; Wang, Y.; Li, X.; Ji, D.; Ren, S.; Gao, X. Surface ozone trend details and interpretations in Beijing, 2001-2006. Atmos. Chem. Phys. 2009, 9, 8813-8823. 
17. Wang, X.Y.; Xin, J.Y.; Wang, Y.S.; Feng, X.X.; Zhang, Y.P. Observation and analysis of air pollution in Tangshan during summer and autumn time. Environ. Sci. 2010, 31, 878-885.

18. Xin, J.Y.; Wang, Y.S.; Tang, G.Q.; Wang, L.L.; Sun, Y.; Wang, Y.H.; Hu, B.; Song, T.; Ji, D.S.; Wang, W.F.; et al. Variability and reduction of atmospheric pollutants in Beijing and its surrounding area during the Beijing 2008 Olympic Games. Chin. Sci. Bull. 2010, 55, 1937-1944.

19. Tang, G.; Wang, Y.; Li, X.; Ji, D.; Gao, X. Spatial-temporal variations in surface ozone in Northern China as observed during 2009-2010 and possible implications for future air quality control strategies. Atmos. Chem. Phys. 2012, 12, 2757-2776.

20. Tangshan Environmental Protection Agency. Tangshan Environment Bulletin. Available online: www.tshbj.net/portal/manage/manage.action?column=e253b3528d2c467b8c9e362a9b5c6280\&art icle=3358424b72dd4b12afa1f16613e9c5f7 (accessed on 18 December 2012).

21. Seinfeld, J.H.; Pandis, S.N. Atmospheric chemistry and physics. In Air Pollution to Climate Changes; Wiley: New York, NY, USA, 1998.

22. Leighton, P.A. Photochemistry of Air Pollution; Academic Press: New York, NY, USA, 1961.

23. Lu, K.D.; Zhang, Y.H.; Su, H.; Shao, M.; Zeng, L.M.; Zhong, L.J.; Xiang, Y.R.; Chang, C.C.; Chou, C.K.C.; Andreas, W. Regional ozone pollution and key controlling factors of photochemical ozone production in Pearl River Delta during summer time. Sci. Chin. 2010, 53, 651-663.

24. Clapp, L.J.; Jenkin, M.E. Analysis of the relationship between ambient levels of $\mathrm{O}_{3}, \mathrm{NO}_{2}$ and $\mathrm{NO}$ as a function of $\mathrm{NO}_{x}$ in UK. Atmos. Environ. 2001, 35, 6391-6405.

25. Lu, W.Z.; He, H.D.; Dong, L.Y. Performance assessment of air quality monitoring networks using principal component analysis and cluster analysis. Build. Environ. 2011, 46, 577-583.

26. Diamantaras, K.I.; Kung, S.Y. Principal Component Neural Networks: Theory and Applications; Wiley: New York, NY, USA, 1996.

27. Cangelosi, R.; Goriely, A. Component retention in principal component analysis with application to cDNA microarray data. Biol. Direct 2007, 2, 1-21.

28. Guo, Y.; Schuurmans, D. Efficient Global Optimization for Exponential Family PCA and Low-Rank Matrix Factorization. In Proceedings of Allerton Conference on Communication Control, and Computing, Urbana, IL, USA, 23-26 September 2008.

29. Olawale, F.; Garwe, D. Obstacles to the growth of new SMEs in South Africa: A principal component analysis approach. Afr. J. Bus. Manag. 2010, 4, 729-738.

30. Corani, G. Air quality prediction in Milan: Feed-forward neural networks, pruned neural networks and lazy learning. Ecol. Model. 2005, 185, 513-529.

31. Gomez-Sanchis, J.; Martin-Guerrero, J.D.; Soria-Olivas, E.; Vila-Frances, J.; Carrasco, J.L.; Valle-Tascon, S.D. Neural networks for analysing the relevance of input variables in the prediction of tropospheric ozone concentration. Atmos. Environ. 2006, 40, 6173-6180.

32. Heo, J.S.; Kim, D.S. A new method of ozone forecasting using fuzzy expert and neural network systems. Sci. Total Environ. 2004, 325, 221-237.

33. Gardner, M.W.; Dorling, S.R. Neural network modelling and prediction of hourly $\mathrm{NO}_{X}$ and $\mathrm{NO}_{2}$ concentrations in urban air in London. Atmos. Environ. 1999, 33, 709-719.

34. Lin, Y.; Lee, Y.; Wahba, G. Support Vector Machines for Classification in Nonstandard Situations; Technical Report 1016 for Department of Statistics, University of Wisconsin: Madison, WI, USA, 2000. 
35. Rish, I.; Grabarnilk, G.; Cecchi, G.; Pereira, F.; Gordon, G. Closed-Form Supervised Dimensionality Reduction with Generalized Linear Models. In Proceedings of the International Conference on Machine Learning (ICML), Helsinki, Finland, 5-9 July 2008.

36. Lu, W.Z.; Wang, D. Ground-level ozone prediction by support vector machine approach with a cost-sensitive classification scheme. Sci. Total Environ. 2008, 395, 109-116.

37. Xu, X.D.; Shi, X.H.; Xie, L.A.; Ding, G.A.; Miao, Q.J.; Ma, J.Z.; Zheng, X.D. Spatial character of the gaseous and particulate state compound correction of urban atmospheric pollution in winter and summer. Sci. Chin. Ser. D Sci. 2005, 35, 53-65.

38. Jacob, D.J. Introduction to Atmospheric Chemistry; Princeton University Press: Princeton, NJ, USA, 1999.

39. Wang, G.C.; Kong, Q.X.; Chen, H.B.; Xuan, Y.J.; Wan, X.W. Characteristics of ozone vertical distribution in the atmospheric over Beijing. Adv. Earth Sci. 2004, 19, 743-748.

40. An, J.L.; Wang, Y.S.; Li, X.; Sun, Y.; Shen, S.H.; Shi, L.Q. Analysis of the relationship between $\mathrm{NO}, \mathrm{NO}_{2}$ and $\mathrm{O}_{3}$ concentrations in Beijing. Environ. Sci. 2010, 28, 706-711.

(C) 2013 by the authors; licensee MDPI, Basel, Switzerland. This article is an open access article distributed under the terms and conditions of the Creative Commons Attribution license (http://creativecommons.org/licenses/by/3.0/). 